Article

\title{
Formation of Nanostructured Carbon from $\left[\mathrm{Ni}\left(\mathrm{NH}_{3}\right)_{6}\right]_{3}\left[\mathrm{Fe}(\mathrm{CN})_{6}\right]_{2}$
}

\author{
Denis P. Domonov ${ }^{1, *}$, Sophiya I. Pechenyuk ${ }^{1}$, Alexander T. Belyaevskii ${ }^{1}$ and \\ Kirill V. Yusenko $2, *$ (i) \\ 1 Tananaev Institute of Chemistry and Technology of Rare Elements and Mineral Raw Materials of RAS \\ KSC (ICTREMR), Akademgorodok, 26a, Apatity, 184209 Murmansk Region, Russia; \\ s.pecheniuk@ksc.ru (S.I.P.); a.beliaevskii@ksc.ru (A.T.B.) \\ 2 Bundesanstalt für Materialforschung und -prüfung BAM, Richard-Willstätter Str. 11, \\ D-12489 Berlin, Germany \\ * $\quad$ Correspondence: d.domonov@ksc.ru (D.P.D.); kirill.yusenko@bam.de (K.V.Y.); Tel.: +7-(81555)-79650 (D.P.D.)
}

Received: 24 January 2020; Accepted: 20 February 2020; Published: 23 February 2020

check for updates

\begin{abstract}
The products of thermal decomposition in an argon atmosphere of $\left[\mathrm{Ni}_{(}\left(\mathrm{NH}_{3}\right)_{6}\right]_{3}\left[\mathrm{Fe}(\mathrm{CN})_{6}\right]_{2}$ as a precursor has been studied. Decomposition products were studied up to $800{ }^{\circ} \mathrm{C}$. Above $600{ }^{\circ} \mathrm{C}$, all coordination bonds in the residues are broken with a formation of $\mathrm{Ni}_{3} \mathrm{Fe}, \mathrm{Fe}$, and free carbon with a small admixture of nitrogen. Elementary carbon can be easily separated from metals by treatment with a water solution of hydrochloric acid. Only carbon is responsible for the specific surface of the composite products. The released carbon has a high degree of graphitization and begins to oxidize in air above $500{ }^{\circ} \mathrm{C}$ and is completely oxidized above $700{ }^{\circ} \mathrm{C}$.
\end{abstract}

Keywords: double complex compound; thermal decomposition; carbon materials

\section{Introduction}

Double complex compounds (DCC) represent a large class of coordination compounds containing coordination cations and coordination anions. Recently, DCC were proposed as promising precursors for the preparation of nanostructured polymetallic alloys [1]. In recent studies, metallic products obtained after thermal decomposition of DCC were also proposed as active heterogeneous catalysts for CO oxidation [2,3]. The thermal decomposition of DCC with $3 d$ metals coordinated with carbon-containing ligands results in a formation of large amounts of residual carbon (20-40 wt.\% of the initial carbon [4-8], in an inert and reducing atmosphere. If DCC contains cyano-groups in an anionic part, residual carbon forms easily in an inert atmosphere. The resulting product of thermal decomposition can be considered as a metal/carbon composite material.

Recently, metal/carbon composites based on pure $\mathrm{Fe}, \mathrm{Co}$, and $\mathrm{Ni}$, as well as their alloys were proposed as effective materials for converting high-frequency electromagnetic radiation into thermal energy [9-11]. So, the thermal decomposition of carbon-containing DCC can be considered as a possible routine to access metal/carbon composites.

Among DCC of the first transition row metals [4,12,13], $\left[\mathrm{Ni}\left(\mathrm{NH}_{3}\right)_{6}\right]_{3}\left[\mathrm{Fe}(\mathrm{CN})_{6}\right]_{2}[4]$ has been investigated in many details to understand its thermal behavior in various atmospheres. It has been shown that it forms the highest amount of residual carbon in an inert atmosphere (up to $50 \%[4,5]$ ). Nevertheless, the process of the formation of residual carbon and its properties have not yet been specifically studied. [ $\left.\mathrm{Ni}\left(\mathrm{NH}_{3}\right)_{6}\right]_{3}\left[\mathrm{Fe}(\mathrm{CN})_{6}\right]_{2}$ seems to be an attractive single-source precursor for the preparation of $\mathrm{Fe}-\mathrm{Ni}-\mathrm{C}$ compositions, since nickel and iron are capable of forming intermetallic compounds, alloys, and spinel type mixed oxides. 
It has been shown that the crystal structure of DCC effects their thermal decomposition [5]. However, low stability of $\left[\mathrm{Ni}\left(\mathrm{NH}_{3}\right)_{6}\right]_{3}\left[\mathrm{Fe}(\mathrm{CN})_{6}\right]_{2}$ makes the determination of its crystal structure and growing its single crystals difficult. $\mathrm{A}\left[\mathrm{Ni}\left(\mathrm{NH}_{3}\right)_{6}\right]^{2+}$ cation undergoes easy hydrolysis in water solution due to its low stability constant (ca. $10^{6}$ ). Therefore, the compound can be successfully prepared in the presence of a large excess of ammonia in water solution. In air, a dry compound loses coordinated ammonia and undergoes fast degradation, so it should be stored in closed vessels under a small amount of ammonia pressure. As a result, only powder diffraction data can be applied for its structural characterization.

In air flow, $\left[\mathrm{Ni}\left(\mathrm{NH}_{3}\right)_{6}\right]_{3}\left[\mathrm{Fe}(\mathrm{CN})_{6}\right]_{2}$ releases coordinated ammonia in two stages at 125 and $300{ }^{\circ} \mathrm{C}$. Coordinated cyanide ligands decompose in the region of $200-480{ }^{\circ} \mathrm{C}$ with the formation of carbon dioxide, nitrogen, and nitrous oxide $[4,5,13]$. The solid residue is a mixture of nickel and iron oxides.

In hydrogen flow, ammonia also releases in two stages. Additionally, ca. 3 mol HCN can be detected. Carbon releases as hydrocarbons, mainly methane, as a product of hydrogenation of cyano-groups to hydrocarbons and ammonia [13]. Above $870{ }^{\circ} \mathrm{C}$, carbon cannot be detected in final solid products; only a mixture of $\mathrm{Ni}_{3} \mathrm{Fe}$ and an $f c c$-structured $\mathrm{Fe}-\mathrm{Ni}$ alloy can be isolated.

In argon flow, ammonia also releases in two stages at 120 and $400{ }^{\circ} \mathrm{C}$. Between 3 and $3.5 \mathrm{~mol}$ of ammonium cyanide releases in a single step at $380^{\circ} \mathrm{C}$. The rest of the carbon remains in the solid phase in the form of cyano-groups, which decompose at $550-600{ }^{\circ} \mathrm{C}$ with the release of molecular nitrogen. 1-2 $\mathrm{N}$ atoms still remain in the solid residue and can be gradually removed by heating above $1000^{\circ} \mathrm{C}$.

In the current study, we perform a detailed investigation of the formation process and the properties of free carbon formed in the solid residue upon the thermal decomposition of $\left[\mathrm{Ni}\left(\mathrm{NH}_{3}\right)_{6}\right]_{3}\left[\mathrm{Fe}(\mathrm{CN})_{6}\right]_{2}$ in an inert atmosphere. The main attention has been paid to understand a process of carbon formation from coordinated cyano-groups.

\section{Materials and Methods}

$\left[\mathrm{Ni}\left(\mathrm{NH}_{3}\right)_{6}\right]_{3}\left[\mathrm{Fe}(\mathrm{CN})_{6}\right]_{2}$ was prepared from water solution by mixing equivalent amounts of [Ni( $\left.\left(\mathrm{NH}_{3}\right)_{6}\right] \mathrm{Cl}_{2}$ (synthesized according to [14]) and $\mathrm{K}_{3}\left[\mathrm{Fe}(\mathrm{CN})_{6}\right]$. For $\mathrm{C}_{12} \mathrm{H}_{54} \mathrm{~N}_{30} \mathrm{Ni}_{3} \mathrm{Fe}_{2}$, calc. (wt.\%): C, 15.9; Ni, 19.4; Fe, 12.3; found (wt.\%): C, 15.8; Ni, 19.7; Fe, 12.3. For $\mathrm{C}_{12} \mathrm{H}_{36} \mathrm{~N}_{24} \mathrm{Ni}_{3} \mathrm{Fe}_{2}$ prepared from [Ni( $\left.\left(\mathrm{NH}_{3}\right)_{6}\right]\left(\mathrm{NO}_{3}\right)_{2}$ : found (wt.\%): C, 17.7; Ni, 21.8; Fe, 14.0; calc. (wt.\%): C, 17.9; Ni, 21.9; Fe, 13.9.

A carbon elemental analysis was performed on an ELTRA CS-2000 (Alpha Resources, LLC, Stevensville, MI, USA) automated analyser. To determine the metal content, weighed portions of the complex or its thermolysis products were dissolved in a mixture of concentrated $\mathrm{HNO}_{3}$ and $\mathrm{HCl}$. The resulting solutions were analyzed by the atomic absorption method on a spectrometer AAnalyst 400 (PerkinElmer, Inc. Waltham, MA, USA). Powder X-ray diffraction (PXRD) patterns of the compound and its thermolysis products (Figure 1) were obtained on a Shimadzu XRD 6000 (Shimadzu Corp., Columbia, MD, USA) diffractometer using $\mathrm{CuK} K_{\alpha}$ radiation (graphite monochromator, $\lambda=1.54 \AA$ ) and were compared with data from the Powder Diffraction File (PDF) database [15]. The diffraction pattern of the starting salt was collected in transmission geometry on a BRUKER Advance diffractometer (BRUKER AG, Karlsruhe, Germany, $\mathrm{Cu} K_{\alpha 1}$ radiation, Johansson monochromator, the sample was placed in a $0.5 \mathrm{~mm}$ glass capillary and sealed in air). The whole-profile Rietveld refinement was performed using Jana2006 [16] (Figure 2). 


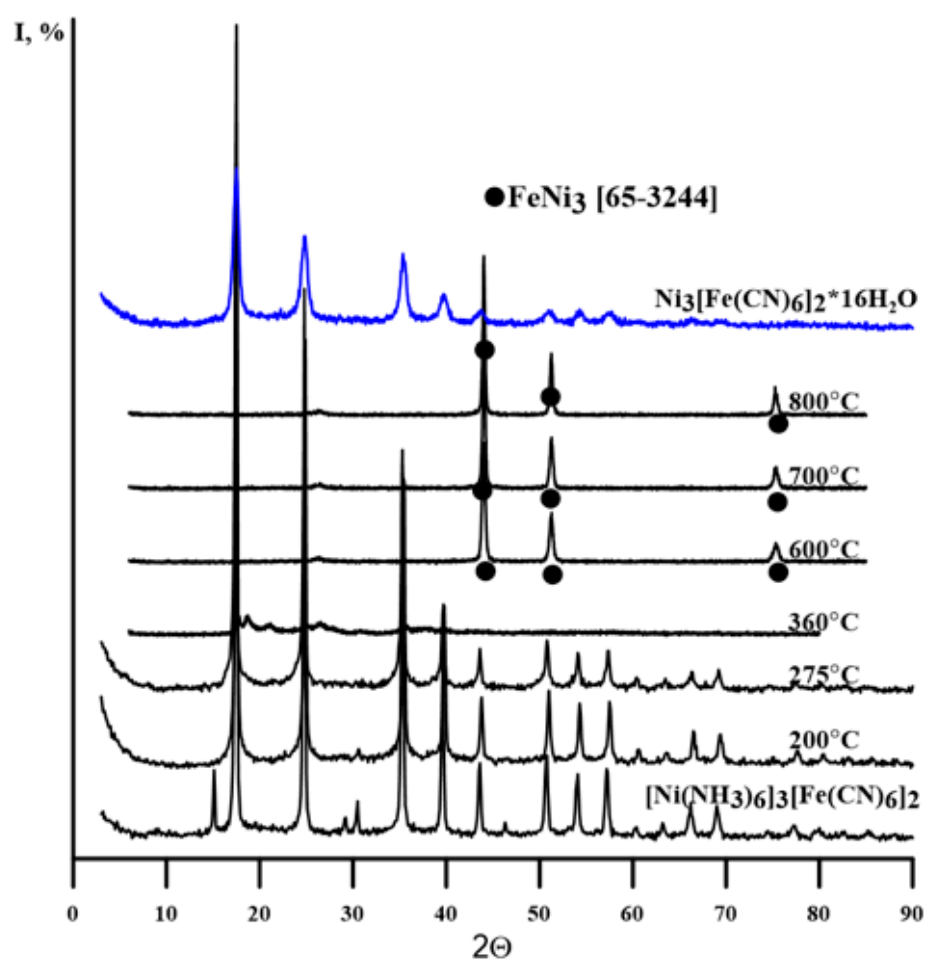

Figure 1. Powder X-ray diffraction (PXRD) patterns of $\left[\mathrm{Ni}\left(\mathrm{NH}_{3}\right)_{6}\right]_{3}\left[\mathrm{Fe}(\mathrm{CN})_{6}\right]_{2}, \mathrm{Ni}_{3}\left[\mathrm{Fe}(\mathrm{CN})_{6}\right]_{2} \cdot 16 \mathrm{H}_{2} \mathrm{O}[4]$ and its thermolysis products.
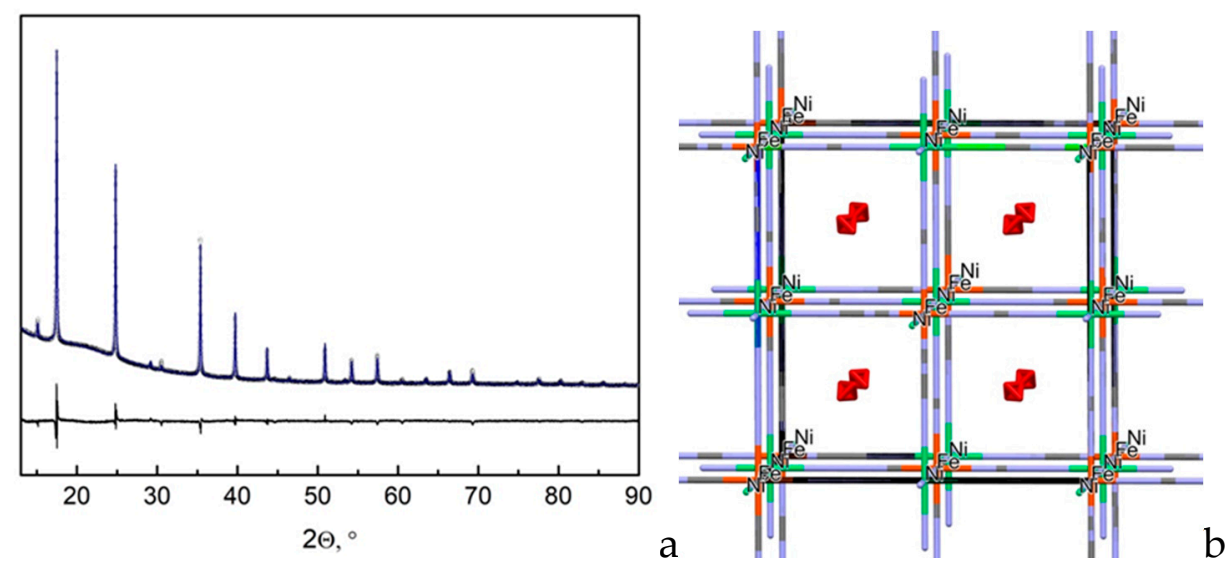

Figure 2. Rietveld refinement corves of the crystal structure of $\left[\mathrm{Ni}\left(\mathrm{NH}_{3}\right)_{4}\right]_{3}\left[\mathrm{Fe}(\mathrm{CN})_{6}\right]_{2}$ (dots-experimental diffractogram; solid line-calculated diffractogram; difference curve is shown below) (a) (left). The model of the crystal structure of $\left[\mathrm{Ni}\left(\mathrm{NH}_{3}\right)_{4}\right]_{3}\left[\mathrm{Fe}(\mathrm{CN})_{6}\right]_{2}$ (disordered ammonia molecules are shown in the middle of the cavities) (b).

The infrared (IR) spectra of the initial complex and solid thermolysis products (Figure 3) were recorded on a Nicolet 6700 FT-IR spectrometer (Thermo Fisher Scientific Inc., Hillsboro, OR, USA) in $\mathrm{KBr}$ pellets. The spectra were interpreted based on [17]. The characteristic absorption maxima in IR spectra are summarized in Table 1. 


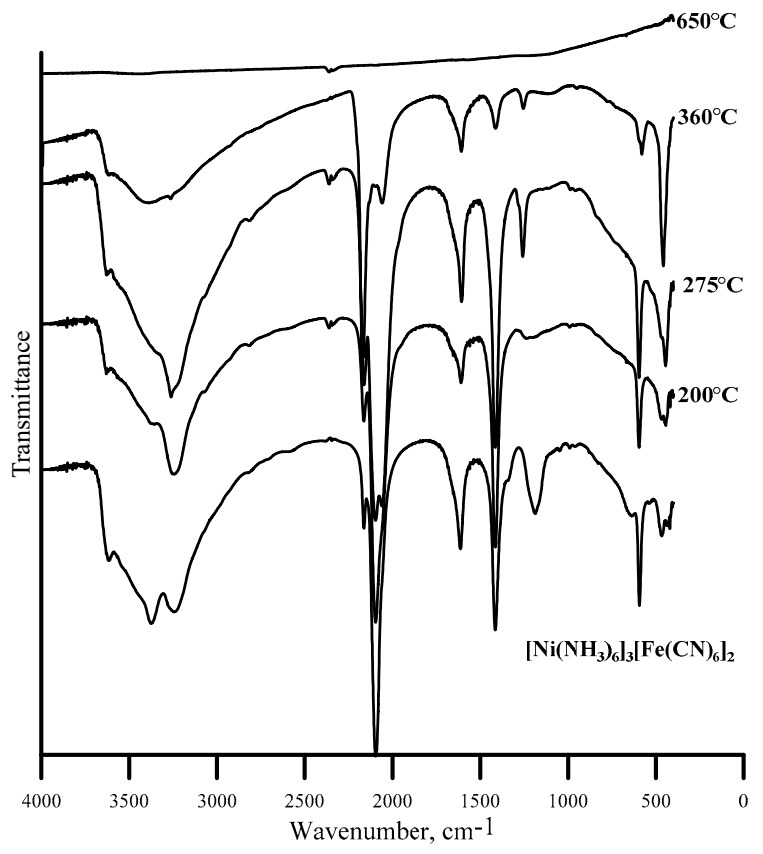

Figure 3. IR spectra of $\left[\mathrm{Ni}\left(\mathrm{NH}_{3}\right)_{6}\right]_{3}\left[\mathrm{Fe}(\mathrm{CN})_{6}\right]_{2}$ and its thermolysis products in argon.

Table 1. Characteristic absorption lines in the IR spectra of thermolysis products.

\begin{tabular}{|c|c|}
\hline Thermolysis Temperature, ${ }^{\circ} \mathrm{C}$ & Absorption Lines, $\mathrm{cm}^{-1}$ \\
\hline starting $\left[\mathrm{Ni}\left(\mathrm{NH}_{3}\right)_{4}\right]_{3}\left[\mathrm{Fe}(\mathrm{CN})_{6}\right]_{2}$ & $\begin{array}{c}3374,3242 v\left(\mathrm{NH}_{3}\right) ; 2169,2095 v(\mathrm{C} \cong \mathrm{N}) ; 1613 \delta_{\mathrm{d}}\left(\mathrm{NH}_{3}\right) ; 1415 \\
\delta_{\mathrm{d}}\left(\mathrm{NH}_{4}\right) ; 1186 \delta_{\mathrm{s}}\left(\mathrm{NH}_{3}\right) ; 594 \rho_{\mathrm{r}}\left(\mathrm{NH}_{3}\right) ; 467 v(\mathrm{M}-\mathrm{N}){ }^{1}\end{array}$ \\
\hline 200 & $\begin{array}{c}3367,3244 v\left(\mathrm{NH}_{3}\right) ; 2163,2097 v(\mathrm{C} \cong \mathrm{N}) ; 1610 \delta_{\mathrm{d}}\left(\mathrm{NH}_{3}\right) ; 1414 \\
\delta_{\mathrm{d}}\left(\mathrm{NH}_{4}\right) ; 596 \rho_{\mathrm{r}}\left(\mathrm{NH}_{3}\right) ; 444 v(\mathrm{M}-\mathrm{N})\end{array}$ \\
\hline 275 & $\begin{array}{c}3261 v\left(\mathrm{NH}_{3}\right) ; 2162,2097,2055 v(\mathrm{C} \cong \mathrm{N}) ; 1607 \delta_{\mathrm{d}}\left(\mathrm{NH}_{3}\right) ; 1414 \\
\delta_{\mathrm{d}}\left(\mathrm{NH}_{4}\right) ; 1258 \delta_{\mathrm{s}}\left(\mathrm{NH}_{3}\right) ; 596 \rho_{\mathrm{r}}\left(\mathrm{NH}_{3}\right) ; 445 v(\mathrm{M}-\mathrm{N})\end{array}$ \\
\hline 360 & $\begin{array}{c}3386,3156 v\left(\mathrm{NH}_{3}\right) ; 2167,2059 v(\mathrm{C} \cong \mathrm{N}) ; 1608 \delta_{\mathrm{d}}\left(\mathrm{NH}_{3}\right) ; 1413 \\
\delta_{\mathrm{d}}\left(\mathrm{NH}_{4}\right) ; 1254 \delta_{\mathrm{s}}\left(\mathrm{NH}_{3}\right) ; 580 \rho_{\mathrm{r}}\left(\mathrm{NH}_{3}\right) ; 457 v(\mathrm{Fe}-\mathrm{N})\end{array}$ \\
\hline
\end{tabular}

${ }^{1}$ The bands at $v<500 \mathrm{~cm}^{-1}$ can be caused by stretching vibrations of both $\mathrm{Ni}-\mathrm{N}$ and $\mathrm{Fe}-\mathrm{C}$ bonds. [17].

The specific surface area was measured on a Tristar 3020 and FlowSorbII 2300 from Micromeritics (Micromeritics Instrument Corp. Norcross, GA, USA). Thermal analysis study (Differential thermal analysis, DTA and Thermogravimetric analysis, TG) was carried out in an argon flow on a NETZSCH STA 409 PC/PG instrument (NETZSCH-Gerätebau GmbH, Selb, Germany) in a corundum crucible with a lid (sample weights $7-10 \mathrm{mg}$, gas flow rate $40 \mathrm{ml} / \mathrm{min}$, heating rate 5 and $10 \mathrm{~K} / \mathrm{min}$, temperature range $\left.20-1000{ }^{\circ} \mathrm{C}\right)$. Thermal analysis curves are presented in Figure 4. 


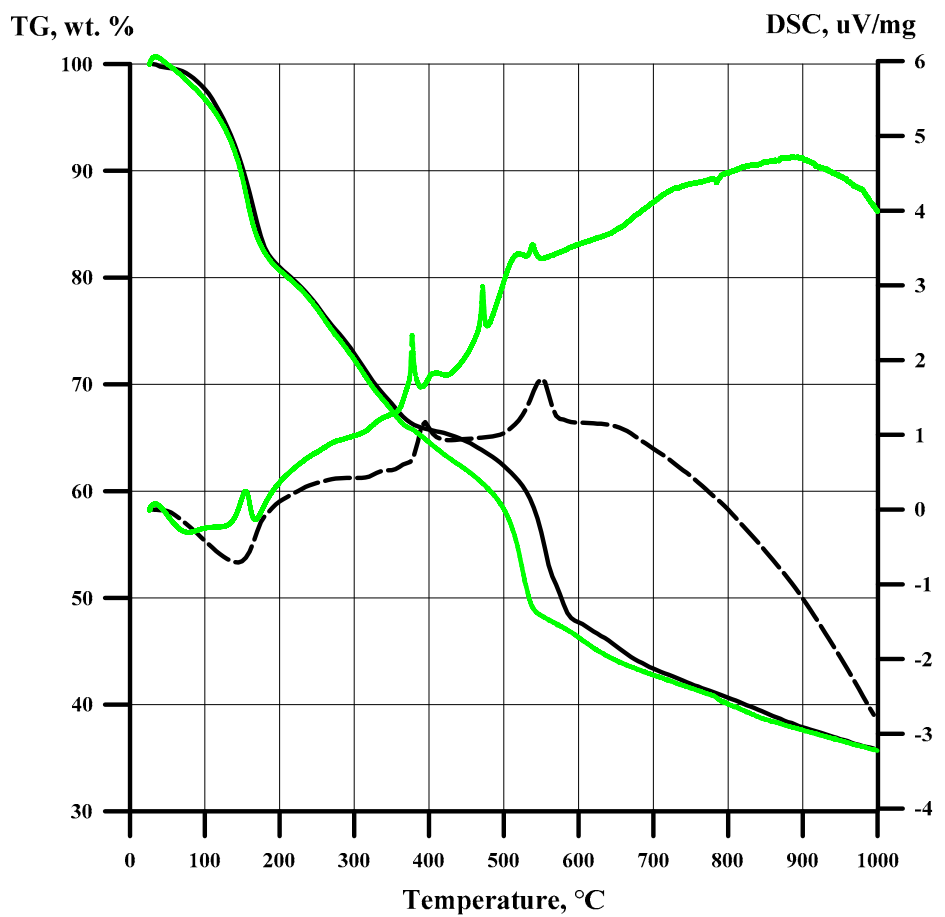

Figure 4. TG and DSC curves for $\left[\mathrm{Ni}\left(\mathrm{NH}_{3}\right)_{6}\right]_{3}\left[\mathrm{Fe}(\mathrm{CN})_{6}\right]_{2}\left(10(-)\right.$ and $\left.5(-)^{\circ} / \mathrm{min}\right)$.

In order to isolate thermolysis products, weighed portions of the compound were heated at a rate of $5{ }^{\circ} \mathrm{C} / \mathrm{min}$ to a predetermined temperature and were then kept at this temperature for $1 \mathrm{~h}$. The samples were placed in quartz vessels and heated in a NaberthermRT 50-250/11 programmable tube furnace (Nabertherm $\mathrm{GmbH}$, Lilienthal, Germany) under argon flow. The products were cooled in an argon atmosphere for $24 \mathrm{~h}$. For the determination of evolved gases, gaseous products were passed through a vessel with Raschig rings cooled by ice and were then passed through two sequential Drexel flasks with an $\mathrm{HCl}$ solution and a mixture of $\mathrm{NaOH}$ and $\mathrm{H}_{2} \mathrm{O}_{2}$ solutions. The amount of ammonia was analysed in acidic solution to obtain the amount of evolved $\mathrm{NH}_{3}$. In alkaline solution, nitrate ions were analysed to obtain amount of evolved $\mathrm{HCN}$.

Carbon was recovered from calcination residues by leaching with cold or hot $6 \mathrm{M} \mathrm{HCl}$. Insoluble carbon was filtered on Schott glass filters No. 3, washed with boiling distilled water, and dried at $100^{\circ} \mathrm{C}$ to constant weight. Carbon prepared by the heating of glucose powder under the same conditions (argon flow in a flow reactor at $700{ }^{\circ} \mathrm{C}$ ) has been used for comparison.

Scanning electron microphotographs were obtained using a SEM Leo 420 instrument (LEO, Assing, Italy).

\section{Results and Discussion}

Nickel(II) weakly coordinates ammonia (see above); therefore, the amount of coordinated ammonia in the inner sphere of nickel(II) species might depend on the nature of the initial nickel salt. The reaction of $\mathrm{Ni}(\mathrm{II})\left[\mathrm{Fe}(\mathrm{CN})_{6}\right]^{3-}$ anions ammonia water solution results in the quick precipitation of double complex salt with a total composition close to $\left[\mathrm{Ni}\left(\mathrm{NH}_{3}\right)_{6}\right]_{3}\left[\mathrm{Fe}(\mathrm{CN})_{6}\right]_{2}$. Its powder X-ray diffraction (PXRD) pattern can be indexed in the cubic space group $F m \overline{3} m$ with $a=10.139(3) \AA$ (Figure 2). [ $\left[\mathrm{Ni}\left(\mathrm{NH}_{3}\right)_{6}\right]_{3}\left[\mathrm{Fe}(\mathrm{CN})_{6}\right]_{2}$ is isostructural to classical Prussian blue compounds, such as $\mathrm{Zn}_{3}\left[\mathrm{Fe}(\mathrm{CN})_{6}\right]_{2} \cdot n \mathrm{H}_{2} \mathrm{O}[18]$, as well as to previously studied $\mathrm{Ni}_{3}\left[\mathrm{Fe}(\mathrm{CN})_{2} \cdot 16 \mathrm{H}_{2} \mathrm{O}\right.$ [4] (Figure 1). In Prussian blue analogous, $\left[\mathrm{Fe}(\mathrm{CN})_{6}\right]^{3-}$ ions occupy corners and centres of the faces in the cubic cell with 2/3 occupancy; $\mathrm{Ni}^{2+}$ cations occupy the middle of the edges and the centre of the unit cell. Crystal water is disordered over several positions and appears in the centres of the cages. Similarly, the structure of $\left[\mathrm{Ni}\left(\mathrm{NH}_{3}\right)_{4}\right]_{3}\left[\mathrm{Fe}(\mathrm{CN})_{6}\right]_{2}$ can be described as a framework formed by $\left[\mathrm{Fe}(\mathrm{CN})_{6}\right]^{3-}$ anions with $\mathrm{Ni}^{2+}$ ions interconnected by $\mathrm{Ni}^{2+}-\mathrm{N}-\mathrm{C}-\mathrm{Fe}^{3+}$ bridges with isolated $\left[\mathrm{Ni}\left(\mathrm{NH}_{3}\right)_{6}\right]^{2+}$ ions surrounded by disordered 
ammonia molecules. In the ideal case, $\mathrm{Ni}^{2+}$ and $\left[\mathrm{Ni}\left(\mathrm{NH}_{3}\right)_{6}\right]^{2+}$ cations should have 2:1 ratio; so, 2/3 of the nickel ions are linked by cyanide bridges to hexacyanide ions, and $1 / 3$ are isolated $\left[\mathrm{Ni}\left(\mathrm{NH}_{3}\right)_{6}\right]^{2+}$. The ammonia molecules should be in the cages of the structure, since the synthesis is carried out from concentrated ammonia solutions. The IR spectra of $\left[\mathrm{Ni}\left(\mathrm{NH}_{3}\right)_{6}\right]_{3}\left[\mathrm{Fe}(\mathrm{CN})_{6}\right]_{2}$ do not show the presence of crystal water in the structure (Table 1 ).

According to the IR spectra, intermediate products obtained at 200,275 , and $360{ }^{\circ} \mathrm{C}$ contain ammonia as well as cyanides coordinated to Fe and Ni. Nevertheless, the absorption intensities are steadily decreasing due to the decreasing of number of coordinated groups (Table 2). At $600-650{ }^{\circ} \mathrm{C}$, coordinated ligands cannot be detected (Figure 3). From the beginning of the curve to $170{ }^{\circ} \mathrm{C}$, there is a mass loss of $19.7 \mathrm{wt} . \%$. Up to $370{ }^{\circ} \mathrm{C}$ TG curves coincide with rates of 5 and $10{ }^{\circ} \mathrm{C} / \mathrm{min}$. The weight loss is $34 \%$. A long flat slope on a TG curve up to $410{ }^{\circ} \mathrm{C}$ gives a weight loss of $14.7 \mathrm{wt} . \%$ and most likely corresponds to ammonia release. A relatively steep decline in TG to 590 (green line) and $535{ }^{\circ} \mathrm{C}$ (black line) gives a weight loss of 21 and $18.5 \mathrm{wt} . \%$. Residues from calcination at $1000{ }^{\circ} \mathrm{C}$ in both cases correspond to $36 \mathrm{wt} . \%$ (Figure 4). Ammonia is gradually removed from the sample up to $360^{\circ} \mathrm{C}$ (Table 2), and with a further increase in the thermolysis temperature, the amount of ammonia released stabilizes at the level of $6-7 \mathrm{~mol} / \mathrm{mol}$ of the complex. As it has been noted in early report [4], it is possible to capture only $1 / 3$ of coordinated ammonia. It can be explained due to the catalytic decomposition of gaseous ammonia in the presence of iron cyanides and metallic nickel [4].

Table 2. The results of the experiments on the thermolysis of $\left[\mathrm{Ni}\left(\mathrm{NH}_{3}\right)_{6}\right]_{3}\left[\mathrm{Fe}(\mathrm{CN})_{6}\right]_{2}$.

\begin{tabular}{|c|c|c|c|c|c|c|c|c|}
\hline \multirow{2}{*}{$\mathrm{T}^{1},{ }^{\circ} \mathrm{C}$} & \multirow{2}{*}{ Residue, wt.\% } & \multirow{2}{*}{ M.m. ${ }^{2}$} & \multicolumn{3}{|c|}{ Composition, wt. $\%$} & \multirow{2}{*}{$\begin{array}{c}\text { Released } \\
\text { Ammonia, mol }\end{array}$} & \multirow{2}{*}{$\mathrm{S}_{\mathrm{sp}}{ }^{3}, \mathrm{~m}^{2} / \mathrm{g}$} & \multirow{2}{*}{ Description of Samples } \\
\hline & & & $\mathrm{Ni}$ & $\mathbf{F e}$ & C & & & \\
\hline \multirow{3}{*}{ starting } & \multirow{3}{*}{100} & 905.7 & 19.44 & 12.3 & $15.9 / 100$ & - & \multirow{3}{*}{-} & $\mathrm{Ni}_{3} \mathrm{Fe}_{2} \mathrm{C}_{12} \mathrm{H}_{54} \mathrm{~N}_{30}=$ \\
\hline & & & & & & & & {$\left[\mathrm{Ni}\left(\mathrm{NH}_{3}\right)_{6}\right]_{3}\left[\mathrm{Fe}(\mathrm{CN})_{6}\right]_{2}$} \\
\hline & & 803.7 & 21.8 & 14.0 & $17.7 / 100$ & - & & $\begin{array}{c}\mathrm{Ni}_{3} \mathrm{Fe}_{2} \mathrm{C}_{12} \mathrm{H}_{36} \mathrm{~N}_{24}= \\
{\left[\mathrm{Ni}\left(\mathrm{NH}_{3}\right)_{4}\right]_{3}\left[\mathrm{Fe}(\mathrm{CN})_{6}\right]_{2}}\end{array}$ \\
\hline \multirow{3}{*}{200} & 83.9 & 736 & 23.9 & 15.1 & 19.7 & - & \multirow{3}{*}{-} & $\begin{array}{c}\mathrm{Ni}_{3} \mathrm{Fe}_{2} \mathrm{C}_{12} \mathrm{H}_{24} \mathrm{~N}_{20}= \\
{\left[\mathrm{Ni}_{3}\left(\mathrm{NH}_{3}\right)_{2}\right]\left[\mathrm{Fe}_{2}(\mathrm{CN})\right][}\end{array}$ \\
\hline & & & & & & & & 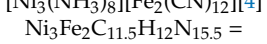 \\
\hline & 79 & 660 & 26.3 & 17.1 & 20.9 & 2.7 & & {$\left[\mathrm{Ni}_{3}\left(\mathrm{NH}_{3}\right)_{4}\right]\left[\mathrm{Fe}_{2}(\mathrm{CN})_{11.5}\right]$} \\
\hline \multirow{2}{*}{275} & 79 & 736 & 23.9 & 15.0 & 19.1 & \multirow{2}{*}{$\overline{4.4}$} & - & $\begin{array}{c}\mathrm{Ni}_{3} \mathrm{Fe}_{2} \mathrm{C}_{12} \mathrm{H}_{24} \mathrm{~N}_{20}= \\
{\left[\mathrm{Ni}_{3}\left(\mathrm{NH}_{3}\right)_{8}\right]\left[\mathrm{Fe}(\mathrm{CN})_{6}\right]_{2}}\end{array}$ \\
\hline & 74 & 630 & 28.1 & 18.0 & 21.2 & & - & $\begin{array}{c}\mathrm{Ni}_{3} \mathrm{Fe}_{2} \mathrm{C}_{11.5} \mathrm{H}_{9} \mathrm{~N}_{15.5}= \\
{\left[\mathrm{Ni}_{3}\left(\mathrm{NH}_{3}\right)_{3}\right]\left[\mathrm{Fe}_{2}(\mathrm{CN})_{11}\right]}\end{array}$ \\
\hline \multirow{2}{*}{360} & \multirow{2}{*}{66.3} & \multirow{2}{*}{600} & 29.7 & 18.2 & $20.4 / 85.1$ & \multirow{2}{*}{5.0} & \multirow{2}{*}{170} & \multirow{2}{*}{$\begin{array}{c}\text { Green residue } \\
\mathrm{Ni}_{3} \mathrm{Fe}_{2}(\mathrm{CN})_{10.4}\end{array}$} \\
\hline & & & 31.4 & 18.7 & & & & \\
\hline 600 & \multirow{2}{*}{$\begin{array}{l}41.08 \\
44.3\end{array}$} & \multirow{2}{*}{$\begin{array}{c}372 \\
401 \\
(375)\end{array}$} & 47.54 & 29.56 & 23.2 & - & 27.71 & $\mathrm{Ni}_{3} \mathrm{Fe}_{2} \mathrm{C}_{7.3}$ \\
\hline 650 & & & - & - & $23.9 / 66.6$ & 6.8 & 40.5 & $\begin{array}{l}\text { Black, loose, } \\
\mathrm{Ni}_{3} \mathrm{Fe}_{2} \mathrm{C}_{7} \mathrm{~N}_{2}\end{array}$ \\
\hline 650 & 44.4 & $\begin{array}{c}402 \\
(375)\end{array}$ & 49.0 & 29.8 & $22.0 / 61.4$ & 6.5 & 43.8 & Sharp lines of $\mathrm{Ni}_{3} \mathrm{Fe}$ \\
\hline 700 & 39.9 & 361 & 48.80 & 31.54 & 18.7 & - & 72.73 & $\mathrm{Ni}_{3} \mathrm{Fe}_{2} \mathrm{C}_{5.5} \mathrm{~N}_{0.5}$ \\
\hline \multirow[t]{2}{*}{800} & 45 & 400 & 44.4 & 28.5 & 21.6 & 6.2 & 78,54 & $\mathrm{Ni}_{3} \mathrm{Fe}_{2} \mathrm{C}_{7} \mathrm{~N}_{2}$ \\
\hline & 41.6 & 377 & 48.43 & 31.23 & 23,6 & - & 77.52 & $\mathrm{Ni}_{3} \mathrm{Fe}_{2} \mathrm{C}_{7} \mathrm{~N}_{0.5}$ \\
\hline 1000 & 46.2 & 400 & 44.4 & 28.1 & 21.0 & - & - & $\mathrm{Ni}_{3} \mathrm{Fe}_{2} \mathrm{C}_{7}[4]$ \\
\hline
\end{tabular}

The XRD patterns (Figure 1) of the initial compound and the thermolysis products at 200 and $275{ }^{\circ} \mathrm{C}$ are almost identical. PXRD patterns can be attributed to a mixture of $\mathrm{Ni}_{2}\left[\mathrm{Fe}(\mathrm{CN})_{6}\right]$ and $\mathrm{Fe}_{4}\left[\mathrm{Fe}(\mathrm{CN})_{6}\right]_{3}$ [15]. The structure of such a mixture should not differ too much from the one described above, since nothing prevents the $\left[\mathrm{Fe}(\mathrm{CN})_{6}\right]^{3-}$ anions and nickel cations to occupy above-mentioned crystallographic positions. However, the IR spectra of thermolysis products below $400{ }^{\circ} \mathrm{C}$ indicate cyano-groups and ammonia that coordinated as well as $\mathrm{NH}_{4}{ }^{+}$. At the same time, bands at 2163, 2097, and $2055 \mathrm{~cm}^{-1}$ detected in the IR spectra of thermolysis products below $400{ }^{\circ} \mathrm{C}$ can be attributed to $\mathrm{Ni}-\mathrm{NC}-\mathrm{Fe}^{\mathrm{II}, \mathrm{III}}$ bonds, which indicates the presence of nickel not surrounded by coordinated ammonia molecules and confirms the structure shown in Figure 2.

A comparison of the previously obtained $[4,5]$ and new data allows us to conclude that in the range $200-400{ }^{\circ} \mathrm{C}$ the products of thermolysis contain from 15 to 2-3 ammonia molecules. At higher temperatures, carbon and nitrogen are retained in the thermolysis product and cannot be indicated in the IR spectra. Previously [4,5], it was shown that ammonium cyanide (hydrogen cyanide) can 
be detected upon thermal decomposition in an inert flow of $\left[\mathrm{Ni}\left(\mathrm{NH}_{3}\right)_{4}\right]_{3}\left[\mathrm{Fe}(\mathrm{CN})_{6}\right]_{2}\left(\right.$ at $\left.310-420^{\circ} \mathrm{C}\right)$. The dissociation of cyano-groups to carbon and nitrogen occurs at $600-650^{\circ} \mathrm{C}$. The PXRD patterns of thermolysis products above $650{ }^{\circ} \mathrm{C}$ show only $\mathrm{Ni}_{3} \mathrm{Fe}$ and Fe reflections.

It is possible to isolate the residual carbon from the products of thermolysis of DCC in an argon atmosphere obtained above $600{ }^{\circ} \mathrm{C}$. Thermolysis product obtained at $360{ }^{\circ} \mathrm{C}$ was dissolved in $\mathrm{HCl}$. After dissolution, ferrocyanide ions were detected in solution. Similar dissolution was performed for products obtained at $600,650,700$, and $800{ }^{\circ} \mathrm{C}$ (Figures $5-7$ ). So, metallic particles can be easily dissolved from the composite in a concentrated $\mathrm{HCl}$ water solution. The amount of carbon obtained from the thermolysis products quite closely corresponds to the analytically determined carbon content and might exceed by 10-30 wt.\%. This carbon contains small Ni and Fe admixtures (Table 3).

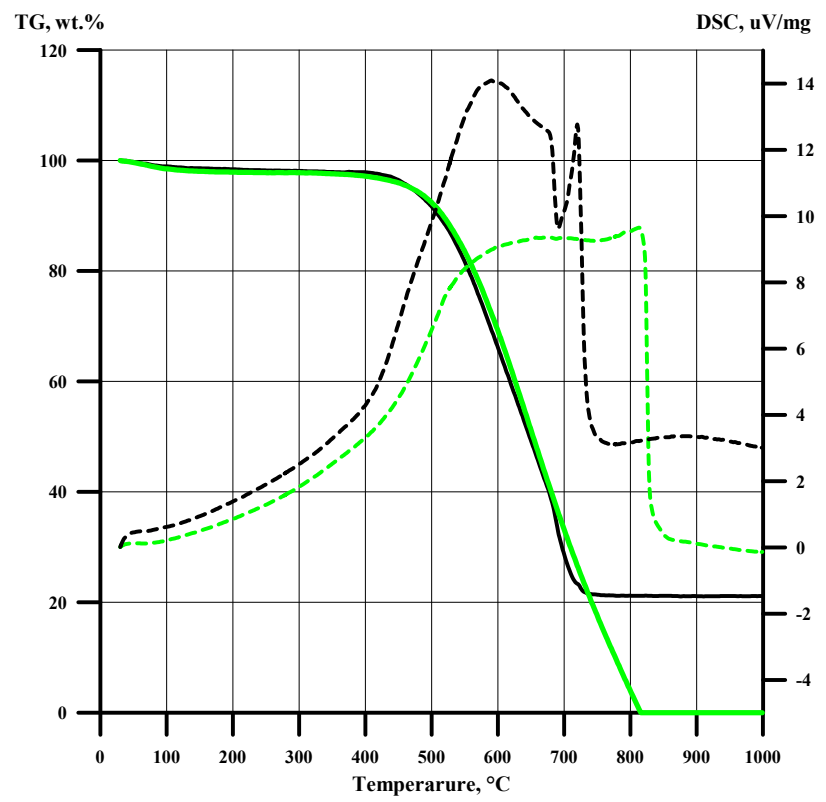

Figure 5. Thermogravimetry (solid lines) and differential thermal analysis (dashed lines) curves of carbon obtained from $\left[\mathrm{Ni}\left(\mathrm{NH}_{3}\right)_{6}\right]_{3}\left[\mathrm{Fe}(\mathrm{CN})_{6}\right]_{2}$ in argon at $700{ }^{\circ} \mathrm{C}(-)$ and from glucose at $900{ }^{\circ} \mathrm{C}(-)$.

Figure 5 shows the curves of thermal analysis in the air of the obtained carbon samples. For comparison, Figures 5 and 6 show the characteristics of the glucose thermolysis product at $900{ }^{\circ} \mathrm{C}$ in argon. Carbons extracted after thermal decomposition of DCC are similar to thermally expanded graphite [19,20]. All samples have high surface areas and are stable in air below $450{ }^{\circ} \mathrm{C}$. In [21], the high-temperature graphitization of carbon materials obtained as products of pyrolysis of the initial fibrous precursor poly ( $p$-phenylenebenzo-bis-oxazole (PBO) were described. It has been found, that even at $2400^{\circ} \mathrm{C}$, the interlayer distance $d_{002}=3.42 \AA$ in graphitic carbon obtained from PBO still exceeds the characteristic value for pure crystalline graphite ( $3.354 \AA)$. Figure 6 shows XRD patterns of carbon samples that were extracted from products of the thermal decomposition of $\left[\mathrm{Ni}\left(\mathrm{NH}_{3}\right)_{4}\right]_{3}\left[\mathrm{Fe}(\mathrm{CN})_{6}\right]_{2}$ at $600-800{ }^{\circ} \mathrm{C}$. Corresponding diffraction $\left(\begin{array}{lll}0 & 0 & 2\end{array}\right)$ peak positions $(2 \theta=c a$. $26^{\circ}$ ) and interlayer distances $d_{002}$ (Figure 6, Table 3) are comparable with the relevant data for PBO graphitization products at $2400{ }^{\circ} \mathrm{C}$ [21]. Carbon obtained from glucose (absence of metal in the initial material) shows no visible crystallinity. It can be an indication for catalytic role of metals from DCC in the low-temperature graphitisation process [22]. 


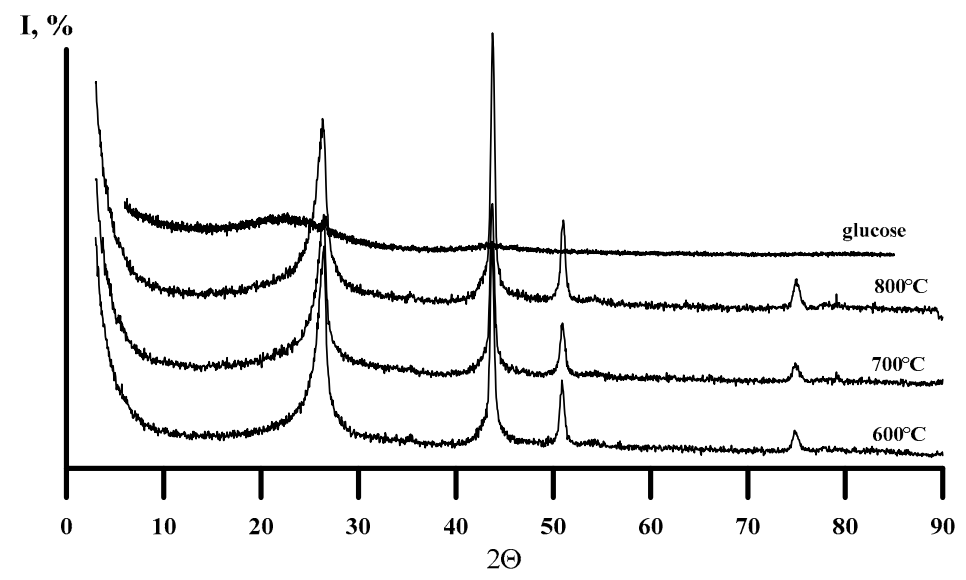

Figure 6. PXRD patterns of carbon samples isolated from thermolysis products and glucose.

Table 3. The yield and properties of carbon from the product thermolysis of $\left[\mathrm{Ni}\left(\mathrm{NH}_{3}\right)_{6}\right]_{3}\left[\mathrm{Fe}(\mathrm{CN})_{6}\right]_{2}$.

\begin{tabular}{|c|c|c|c|c|c|c|}
\hline \multirow{2}{*}{$\begin{array}{l}\text { Thermolysis } \\
\text { Temperature, }{ }^{\circ} \mathrm{C}\end{array}$} & \multirow{2}{*}{$\begin{array}{c}\text { Carbon Yield, } \\
\text { g/g }\end{array}$} & \multirow{2}{*}{$\begin{array}{l}\mathrm{S}_{\mathrm{sp}} \\
\mathrm{m}^{2} / \mathrm{g}\end{array}$} & \multirow{2}{*}{$d_{002, \AA}$} & \multirow{2}{*}{$\begin{array}{l}\text { Crystallite } \\
\text { Size, nm }\end{array}$} & \multicolumn{2}{|c|}{$\begin{array}{l}\text { Content of Metals in } \\
\text { Carbon, wt. } \%\end{array}$} \\
\hline & & & & & $\mathrm{Ni}$ & $\mathrm{Fe}$ \\
\hline 600 & 0.30 & 224 & 0.341 & 14 & - & - \\
\hline \multirow{2}{*}{650} & 0.27 & 148 & 0.337 & 36 & 4.2 & 3.4 \\
\hline & 0.24 & 226 & 0.335 & 38 & - & - \\
\hline 700 & 0.28 & 276 & 0.341 & 14 & 8.03 & 6.77 \\
\hline \multirow{2}{*}{800} & 0.33 & 230 & 0.343 & 40 & 10.4 & 7.5 \\
\hline & 0.30 & 209 & 0.341 & 42 & 8.44 & 6.12 \\
\hline
\end{tabular}

The total specific surface area characteristic for obtained carbon powders is similar to the total surface area of composites before the dissolution of metals. For example, the residue from the calcination of the complex in argon flow at $650{ }^{\circ} \mathrm{C}$ has a specific surface area of $140.5 \mathrm{~m}^{2} / \mathrm{g}$ and a residual carbon content of $23.9 \mathrm{wt}$ \%. From $3.0 \mathrm{~g}$ of the residue, $0.82 \mathrm{~g}$ of carbon with a specific surface of $148 \mathrm{~m}^{2} / \mathrm{g}$ was obtained. The total surface of $3.0 \mathrm{~g}$ of the residue is $121.5 \mathrm{~m}^{2}$; the surface of $0.82 \mathrm{~g}$ carbon obtained after dissolution of metals is $121.4 \mathrm{~m}^{2} / \mathrm{g}$ (Table 3). The ratio between the $S_{s p}$ of residues from calcination and the carbon released from them suggests that, in the residue from calcination, carbon envelops metal particles, providing the entire surface of the residue from calcination.

Figure 7a shows that the initial complex is crystallized in the form of hexagonal plates with a size of 1.5-2 microns. The thermolysis product (Figure $7 \mathrm{~b}$ ) has a loose fibrous structure with a fibre thickness of $0.5-1 \mu \mathrm{m}$. Almost the same structure is preserved for the released carbon (Figure 7c). The diameter of the fibre is $1-2 \mu \mathrm{m}$. 

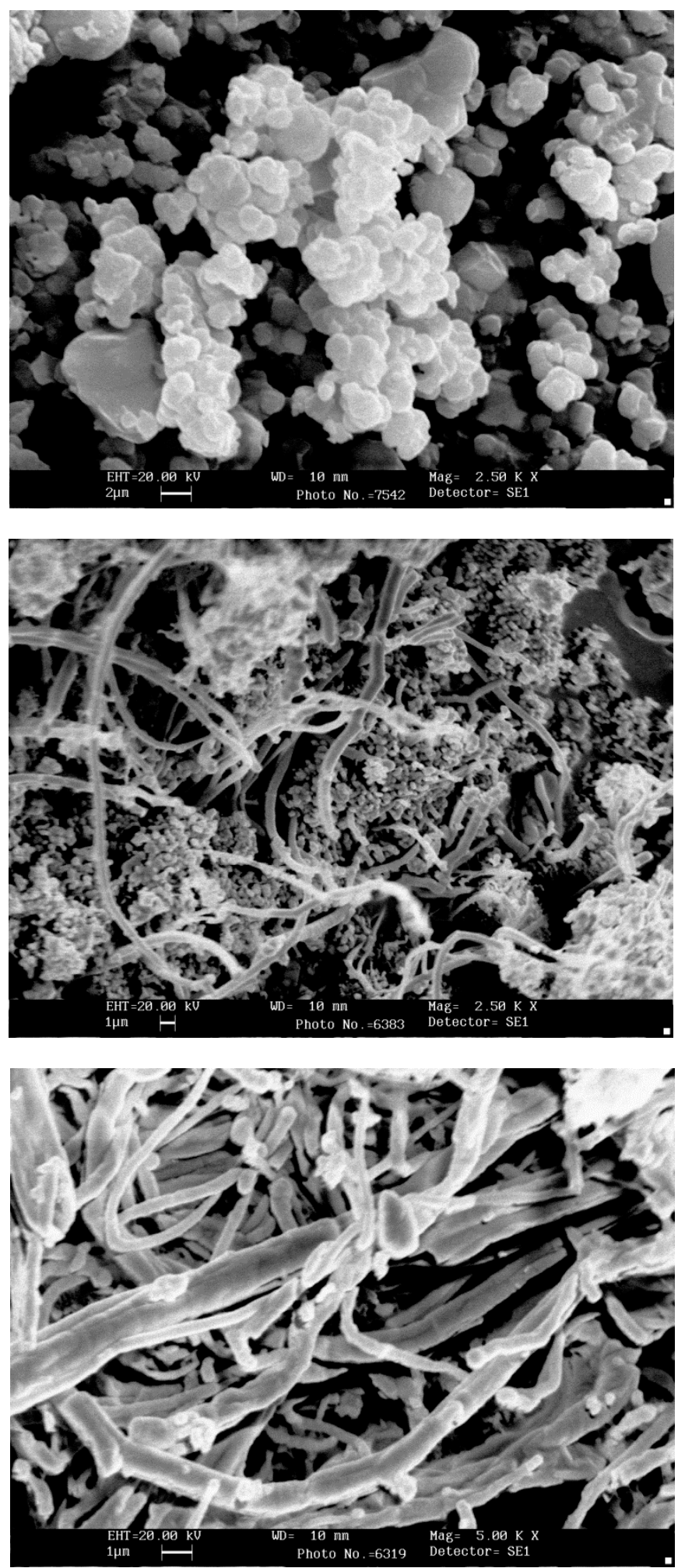

Figure 7. Micrographs of $\left[\mathrm{Ni}\left(\mathrm{NH}_{3}\right)_{6}\right]_{3}\left[\mathrm{Fe}(\mathrm{CN})_{6}\right]_{2}(\mathbf{a})$, its thermolysis product at $650{ }^{\circ} \mathrm{C}(\mathbf{b})$, and carbon (c) isolated from the thermolysis product at $650{ }^{\circ} \mathrm{C}$.

\section{Conclusions}

$\left[\mathrm{Ni}\left(\mathrm{NH}_{3}\right)_{6}\right]_{3}\left[\mathrm{Fe}(\mathrm{CN})_{6}\right]_{2}$ obtained from concentrated ammonia solutions has a complex crystal structure. Its cubic lattice is formed by $\left[\mathrm{Fe}(\mathrm{CN})_{6}\right]^{3-}$ ions occupying the tops and centres of the faces, where the $\mathrm{Ni}^{2+}$ and $\left[\mathrm{Ni}\left(\mathrm{NH}_{3}\right)_{6}\right]^{2+}$ occupy the midpoints of the edges and the centres of the cell. The voids 
in the crystal structure are probably occupied by ammonia molecules. Upon thermal decomposition in an inert atmosphere, $\mathrm{NH}_{3}$ ligands can be removed in two stages. At the first stage (below $300^{\circ} \mathrm{C}$ ), ammonia can be removed from the voids. Further heating results in coordinated ammonia evolving. Nevertheless, at $300{ }^{\circ} \mathrm{C}$, coordinated ammonia molecules can still be obtained in samples. Above $360^{\circ} \mathrm{C}$, only traces of ammonia can be detected. Above $600{ }^{\circ} \mathrm{C},\left[\mathrm{Ni}\left(\mathrm{NH}_{3}\right)_{6}\right]_{3}\left[\mathrm{Fe}(\mathrm{CN})_{6}\right]_{2}$ completely degrades with a formation of $\mathrm{Ni}_{3} \mathrm{Fe}, \mathrm{Fe}$, and carbon with a small nitrogen admixture. Since carbon was present only in the anion, it is undeniable that it is a decomposition product of coordinated cyano-groups. Metals can be easily leached from residues by acid treatment. Residual carbons show a significant degree of graphitization. The ratio between the $S_{\mathrm{sp}}$ of residues from calcination and the carbon released from them suggests that, in the residue from calcination, carbon envelops metal particles, providing the entire surface of the residue.

Author Contributions: Conceptualization, D.P.D. and S.I.P.; Methodology, S.I.P.; Investigation, data analysis and validation, D.P.D., S.I.P.; PXRD analysis, K.V.Y.; scanning electron microscopy A.T.B. Original draft preparation, S.I.P.; all authors contributed to writing and editing the manuscript. All authors have read and agreed to the published version of the manuscript.

Conflicts of Interest: The authors declare no conflicts of interest.

\section{References}

1. Korenev, S.V.; Venediktov, A.B.; Shubin, Y.V.; Gromilov, S.A.; Yusenko, K.V. Synthesis and Structure of Binary Complexes of Platinum Group Metals - Precursors of Metallic Materials. J. Struct. Chem. 2003, 44, 46-59. [CrossRef]

2. Shubin, Y.V.; Korenev, S.V. Formation of Nanosized Bimetallic Particles Based on Noble Metals. Catal. Ind. 2010, 2, 20-25. [CrossRef]

3. Zadesenets, A.V.; Garkul, I.A.; Filatov, E.Y.; Plyusnin, P.E.; Filippov, T.N.; Asanova, T.I.; Korolkov, I.V.; Baidina, I.A.; Asanov, I.P.; Korenev, S.V. Oxalato complexes of Pd(II) with $\mathrm{Co}(\mathrm{II})$ and $\mathrm{Ni}$ (II) as single-source precursors for bimetallic nanoalloys. J. Therm. Anal. Calorim. 2019, 138, 111-121. [CrossRef]

4. Pechenyuk, S.I.; Domonov, D.P.; Shimkin, A.A.; Ivanov, Y.V. Thermal decomposition of iron cyano-complexes in an inert atmosphere. Russ. Chem. Bull. 2015, 64, 322-328. [CrossRef]

5. Pechenyuk, S.I.; Domonov, D.P.; Shimkin, A.A.; Semushina, Y.P.; Ivanov, Y.V. Thermal behavior of binary complex compounds containing the hexacyanoferrate anion. Russ. J. Gen. Chem. 2017, 87, 2212-2223. [CrossRef]

6. Ng, C.W.; Ding, J.; Shi, Y.; Gan, L.M. Structure and magnetic properties of copper(II) hexacyanoferrate(III) copounds. J. Phys. and Chem. Solids 2001, 62, 767-775. [CrossRef]

7. Ng, C.W.; Ding, J.; Wang, L.; Gan, L.M.; Quek, C.H. Thermal-Induced Microstructural Changes of Nickel-Iron Cyanide. J. Pys. Chem. A 2000, 104, 8814-8822. [CrossRef]

8. Ng, C.W.; Ding, J.; Gan, L.M. Microstructural Changes Induced by Thermal Treatment of Cobalt(II) Hexacyanoferrate (III) Compound. J. Solid State Chem. 2001, 156, 400-407. [CrossRef]

9. Song, Z.; Liu, X.; Sun, X.; Li, Y.; Nie, X.; Tang, W.; Yu, R.; Shui, J. Alginate-templated synthesis of CoFe/carbon fiber composite and the effect of hierarchically porous structure on electromagnetic wave absorption performance. Carbon 2019, 151, 36-45. [CrossRef]

10. Ye, F.; Song, Q.; Zhang, Z.C.; Li, W.; Zhang, S.Y.; Yin, X.W.; Zhou, Y.; Tao, H.; Liu, Y.; Cheng, L.; et al. Direct growth of edge-rich graphene with tunable dielectric properties in porous Si3N4 ceramic for broadband high-performance microwave absorption. Adv. Funct. Mater. 2018, 28, 1707205. [CrossRef]

11. Shahzad, F.; Alhabeb, M.; Hatter, C.B.; Anasori, B.; Man Hong, S.; Koo, C.M.; Gogotsi, Y. Electromagnetic interference shielding with 2D transition metal carbides (MXenes). Science 2016, 353, 1137-1140. [CrossRef] [PubMed]

12. Pechenyuk, S.I.; Domonov, D.P.; Rogachev, D.L.; Belyaevskii, A.T. Anion effect on the thermolysis of double complexes $\left[\mathrm{Co}\left(\mathrm{NH}_{3}\right)_{6}\right]\left[\mathrm{Fe}(\mathrm{CN})_{6}\right]$ and $\left[\mathrm{Co}\left(\mathrm{NH}_{3}\right)_{6}\right]_{4}\left[\mathrm{Fe}(\mathrm{CN})_{6}\right]_{3}$. Russ. J. Inorg. Chem. 2007, 52, 1033-1038. [CrossRef]

13. Pechenyuk, S.I.; Domonov, D.P.; Avedisyan, A.A.; Ikorskii, S.V. Conversions of coordinated ligands by reducing thermolysis of some double complex compounds. Russ. Inorg. Chem. 2010, 55, 734-738. [CrossRef] 
14. Brauer, G. Handbuch der Präparativen Anorganischen Chemie: In Drei Bänden; Ferdinand Enke: Stuttgart, Germany, 1978; 2113p.

15. JCPDS-JCDD Card. Newtown Square (PA, USA): International Centre for Diffraction Data; JCPDS-JCDD Card: Newtown Square, PA, USA, 2002.

16. Petříček, V.; Dušek, M.; Palatinus, L. Crystallographic computing system JANA2006: General Features. Z. Kristallogr. 2014, 229, 345-352. [CrossRef]

17. Nakamoto, K. Infrared and Raman Spectra of Inorganic and Coordination Compounds, 6th ed.; Part A: Theory and Applications in Inorganic Chemistry; John Wiley \& Sons: Hoboken, NJ, USA, 2009; 432p.

18. Gravereau, P.; Garnier, E. Structure de la phase cubique de l'hexacyanoferrate(III) de zinc: $\mathrm{Zn}_{3}\left[\mathrm{Fe}(\mathrm{CN})_{6}\right]_{2} \cdot \mathrm{nH}_{2} \mathrm{O}$. Acta Crystallogr. Sect. C 1984, 40, 1306-1309. [CrossRef]

19. Makhorin, K.E.; Zayats, N.N.; Donchak, S.S. Analiz derivatogramm okislennogo i vspuchennogo grafita. Khim. tekhnologiya. 1990, 3, 44-47. (In Russian)

20. Kalashnikova, M.Y. Derivatographic study of thermally expanded graphite products. Vestnik PGTU. Problems of modern materials and technologies. Permian 2001, 7, 82-91. (In Russian)

21. Vazquez-Santos, M.B.; Geissler, E.; Laszlo, K.; Rouzaud, J.N.; Martinez-Alonso, A.; Tascon, J.M.D. Comparative XRD, Raman and TEM Study on graphition of PBO-derived Carbon Fibers. J. Phys. Chem. C 2012, 116, 257-268. [CrossRef]

22. Domrachev, G.A.; Lazarev, A.I.; Kaverin, B.S.; Egorochkin, A.N.; Ob"edkov, A.M.; Domracheva, E.G.; Markin, G.V.; Huipe Nava, E.; Sorokin, A.A.; Suvorova, O.N.; et al. The Role of Carbon and Metal in Self-Assembly of the Iron-Carbon System at Various Component Ratios. Phys. Solid State. 2004, 46, 1969-1983. [CrossRef]

(C) 2020 by the authors. Licensee MDPI, Basel, Switzerland. This article is an open access article distributed under the terms and conditions of the Creative Commons Attribution (CC BY) license (http://creativecommons.org/licenses/by/4.0/). 